\title{
Incidence of Ocular Complications in Patients Undergoing Renal Transplantation
}

\author{
R. PORTER, A. L. CROMBIE, P. S. GARDNER, R. P. ULDALL
}

British Medical fournal, 1972, 3, 133-136

\section{Summary}

The eyes of 39 patients who had received allogenic renal transplants were examined for signs of disease. Nine $(23 \%)$ had early posterior subcapsular cataracts, two $(5 \%)$ developed acute cytomegalovirus retinitis, and one developed steroid-induced glaucoma. The lesions which were found were all attributable to the immunosuppressive drug therapy. Thirty-five $(87 \%)$ had detectable complement-fixing antibodies to cytomegalovirus.

\section{Introduction}

Reports of ocular complications in patients who have had renal transplantation operations are few but have been increasing in recent years (Wallow, 1969; Kern et al., 1970; de Venecia et al., 1971). These complications have almost entirely been attributed to the side effects of the immunosuppressive therapy necessary in such patients, and the ocular complications of these drugs when used in the past for other conditions are well documented (Black et al., 1960; Giles et al., 1962; Ashton and Cunha Vaz, 1966; Williamson et al., 1969).

The purpose of this investigation was to determine for the first time the incidence of ocular complications in a comparatively large series of patients who had received a transplanted kidney, and to assess their severity to see if such patients, or a selected few, might benefit from routine ocular screening either before or after renal transplantation.

\section{Patients and Methods}

The 39 patients in this series (average age 30 years-22 men aged 18-48 and 17 women aged 17-50) had all developed

Royal Victoria Infirmary, Newcastle upon Tyne

R. PORTER, M.B., F.R.C.S., Senior Surgical Registrar

A. L. CROMBIE, M.B., F.R.C.S., Consultant Ophthalmologist

S. GARDNER, M.D., D.BACT., Consultant Virologist and Honorary
Reader, University Department of Virology

\begin{tabular}{l} 
R. R. ULDALL, M.D., M.R.C.P., Consultant Physician, Renal Unit \\
\hline
\end{tabular}

chronic renal failure and had been treated with regular haemodialysis for 3 to 18 months before undergoing a unilateral allogenic renal transplantation. After this they had been treated with an immunosuppressive regimen of azathioprine $150-200 \mathrm{mg}$ daily and prednisone, the dosage of which was altered depending on the intensity of the rejection phenomena. In nine patients cyclophosphamide was added to reinforce the immunosuppressive therapy and 18 patients received local deep $x$-ray therapy to the transplanted kidney in the immediate postoperative period. An equivalent number of controls matched for age and sex were also examined. The patients of this second group also suffered from chronic renal failure and were being treated by regular haemodialysis.

The eyes were examined, after full pupillary dilatation, with a slit-lamp and by direct and indirect ophthalmoscopy. The intraocular pressures were measured with an applanation tonometer, and any patients with intraocular pressures above $20 \mathrm{~mm} \mathrm{Hg}$ had their corneoscleral angles examined and their visual fields charted by means of a Goldman perimeter. Serum was also taken for estimation of the levels of complement-fixing antibodies to the Rawles strain of cytomegalovirus.

\section{Results}

Altogether 13 patients were found to have ocular abnormalities. Nine had posterior subcapsular cataracts, two had acute cytomegalovirus retinitis, one had steroid-induced glaucoma, and one had a right homonymous field defect. In the control group one 50-year-old woman had early peripheral cortical lens opacities, and one man was initially found to have intraocular pressures of $22 \mathrm{~mm} \mathrm{Hg}$ right and $25 \mathrm{~mm} \mathrm{Hg}$ left. Subsequent readings, however, proved normal, as did his visual fields and corneoscleral angles.

\section{POSTERIOR SUBCAPSULAR CATARACTS}

All the cataracts seen were at a very early stage and none of the patients affected had noticed a significant reduction in their vision, the lowest vision in this group being $6 / 12$. Total steroid dosage for 3 and 12 months postoperatively was calculated and, as was expected, there was a significant correlation between high steroid dosage and these cataracts. In fact the eight highest 
total steroid dosages recorded in this series corresponded with eight of the cataracts, and the patient with the remaining cataract, although he had a comparatively low steroid dosage postoperatively, had been intermittently treated before operation with moderate doses of steroids for nine years for his proliferative glomerulonephritis. Other possible cataractogenic factors were correlated, including treatment with cyclophosphamide and deep $x$-ray therapy to the kidney, as is shown in Table I. Statistical analysis showed that there was a significant correlation between total steroid dosage and the formation of

TABLe 1-Total Steroid Dosages 3 and 12 Months Postoperatively in the Nine Patients with Posterior Subcapsular Cataracts

\begin{tabular}{|c|c|c|c|c|c|c|}
\hline \multirow{2}{*}{$\begin{array}{l}\text { Case } \\
\text { No. }\end{array}$} & \multirow{2}{*}{$\begin{array}{c}\text { Time from } \\
\text { Operation to } \\
\text { First Exami- } \\
\text { nation } \\
\text { (Months) }\end{array}$} & \multicolumn{2}{|c|}{$\begin{array}{c}\text { Steroid } \\
\text { Dosage (g) }\end{array}$} & \multirow{2}{*}{$\begin{array}{l}\text { Posterior } \\
\text { subcapsular } \\
\text { Cataract }\end{array}$} & \multirow{2}{*}{$\begin{array}{c}\text { Cyclophos- } \\
\text { phamide } \\
\text { Given }\end{array}$} & \multirow{2}{*}{$\begin{array}{l}\text { No. of } \\
\text { Deep } x \text {-ray } \\
\text { Treatments }\end{array}$} \\
\hline & & $\begin{array}{l}\text { After } 3 \\
\text { months }\end{array}$ & $\begin{array}{l}\text { After } 12 \\
\text { months }\end{array}$ & & & \\
\hline $\begin{array}{l}28 \\
10 \\
20 \\
24 \\
18 \\
71 \\
21 \\
26 \\
12\end{array}$ & $\begin{array}{l}15 \\
24 \\
19 \\
18 \\
21 \\
36 \\
18 \\
17 \\
26\end{array}$ & $\begin{array}{l}6.9 \\
7 \cdot 4 \\
8.8 \\
8 \cdot 0 \\
7 \cdot 3 \\
7 \cdot 8 \\
6 \cdot 6 \\
7 \cdot 7 \\
2.5\end{array}$ & \begin{tabular}{r|}
14.5 \\
$14 \cdot 2$ \\
$14 \cdot 1$ \\
$12 \cdot 8$ \\
$12 \cdot 4$ \\
$12 \cdot 2$ \\
$12 \cdot 1$ \\
6.4
\end{tabular} & $\begin{array}{l}\text { Both eyes } \\
\text { Both eyes } \\
\text { Right eye } \\
\text { Left eye } \\
\text { Both eyes } \\
\text { Right eye } \\
\text { Left eye } \\
\text { Both eyes } \\
\text { Left eye }\end{array}$ & $\begin{array}{l}\text { Yes } \\
\text { Yes } \\
\text { Yes } \\
\text { Yes } \\
\text { No } \\
\text { Yes } \\
\text { Yes } \\
\text { Yes } \\
\text { No }\end{array}$ & $\begin{array}{c}2 \\
2 \\
1 \\
\text { None } \\
1 \\
6 \\
\text { None } \\
3 \\
\text { None }\end{array}$ \\
\hline
\end{tabular}

posterior polar cataract $(P<0 \cdot 05)$. No significant correlation was obtained between the formation of these cataracts and any of the other therapeutic agents.

Cases 10, 26, and 28 also received more normal doses of steroids for their original renal condition before renal failure. Of the 39 patients eight $(20 \%)$ similarly received normal doses of steroids before their final renal failure.

In the control group $7(17 \%)$ had received steroids before starting regular haemodialysis. Case 10 was also found to have a bilateral acute retinitis, so the cataracts could not be definitely attributed to the steroids.

\section{ACUTE RETINITIS}

Two patients developed the more serious condition of an acute retinitis. In one patient it rapidly spread through both eyes, destroying most of the retina and producing virtual blindness. In the second patient it seriously reduced the vision in one eye. Their case histories are of interest.

\section{Case 1}

A 27 -year-old man received a transplanted kidney from his brother in March 1969 having been treated with regular haemodialysis for the previous three months. Fifteen days postoperatively when his creatinine clearance had risen to $35 \mathrm{ml} / \mathrm{min}$ he developed an acute swelling of his left parotid gland with a pronounced pyrexia, but despite the fact that no organisms were cultured it responded to ampicillin and cloxacillin. A renal biopsy specimen one month postoperatively continued to show signs of severe rejection and cyclophosphamide was added to the immunosuppressive therapy of prednisone and azothioprine. His renal function then improved and he was discharged 10 weeks postoperatively.

Two weeks later he was readmitted with left-sided pleuritic pain and a swinging temperature. No clinical or radiological signs of pulmonary disease could be found and his symproms gradually settled. One month later, however, he developed a small left-sided spontaneous pneumothorax which eventually resolved on bed rest. He remained well until September 1970, when he developed a painful effusion of his left knee. This was subsequently found on surgical exploration to be an area of "osteochondritis dissecans" secondary to an area of ischaemic bone necrosis. He had no symptoms referrable to his eyes until February 1971, when the vision in his right eye, already reduced by hyper.ensive retinopathy, deteriorated. He was found to have signs of a panuveitis with optic atrophy and destruction of most of the retina with sclerosed retinal vessels but with little secondary clumping of the retinal pigment. The left eye was normal with a vision of $6 / 6$ but three weeks later this dropped to $6 / 12$ and he was found to have a peripheral area of acute necrotizing retinitis, which in the space of four days spread to involve the whole of the retina and reduce the vision to hand movements.

The ophthalmoscopic picture was striking at that stage (see $z$ Figure), with a yellow oedematous retina covered with numerous

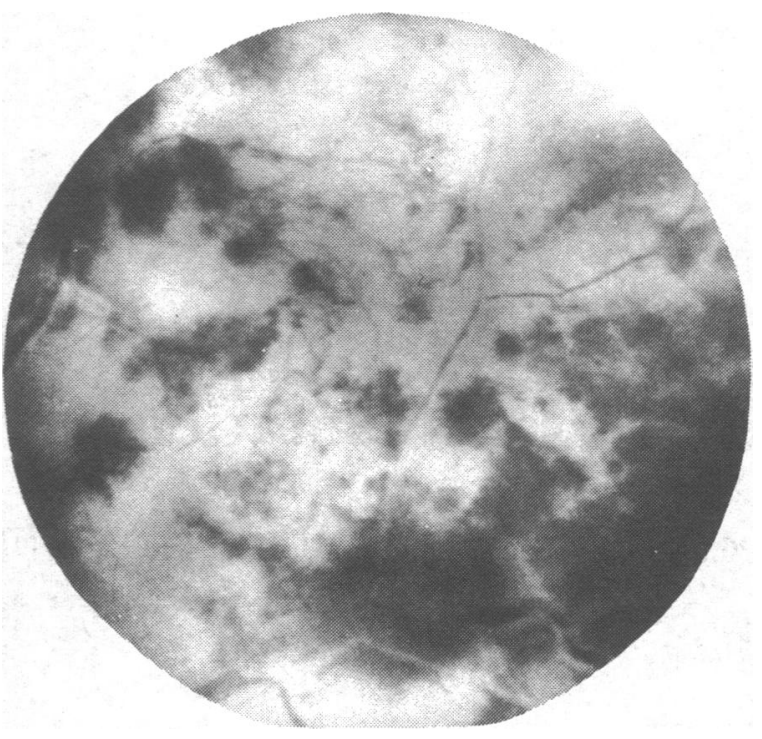

View of left fundus in Case 1 showing areas of pale oedematous retina with numerous retinal haemorrhages, together with thrombosed retinal veins and sclerosed occluded retinal arteries.

retinal haemorrhages. These came from thrombotically occluded retinal veins, and the retinal arteries were equally sclerosed and occluded. The acute phase regressed to leave a fundal picture similar to that of the right eye and final vision of $3 / 60$ on the right and $3 / 36$ on the left. During this period he remained generally well; he was apyrexial and his renal function was satisfactory. But in the period from July to December his antibody titre to cytomegalovirus rose from $1 / 160$ to $1 / 640$. His persistent rejection phenomenon had necessitated large doses of immunosuppressive drugs and he had received $7.4 \mathrm{~g}$ and $14.2 \mathrm{~g}$ of prednisone in the first 3 and 12 months postoperatively, together with $40 \mathrm{mg}$ of cyclophosphamide daily.

\section{Case 2}

A 36-year-old man developed chronic renal failure after mem- N branous glomerulonephritis. He had a bilateral nephreotomy in $D$ April 1969 and was kept on regular haemodialysis until February 1970, when he received a cadaver kidney transplant. His recovery was uneventful apart from a vigorous rejection phenomenon. He remained well until April 1971, when the vision in his right eye $\omega$ fell to $6 / 12$ and he was tound to have a hazy vitreous and an area of acute retinitis on the temporal side, which was typified by 0 large clumps of white exudate and small retinal haemorrhages together with sheathing and occlusion of the retinal vessels. This progressed to involve most of the fundus in the next six months and finally reduced the vision to counting fingers. This patient had also developed an area of ischaemic bone necrosis on the head of his right femur. but apart from that he remained well and apyrexial. His antibody titres to cytomegalovirus on four occasions from August to January were $1 / 320,1 / 640,1 / 1,280$, and $1 / 2,80$. $\mathrm{He}, \mathrm{too}$, required high doses of steroids, receiving $7.3 \mathrm{~g}$ and $12.4 \mathrm{~g}$ of prednisone in the first 3 and 12 months postoperatively.

TABLE I-Number of Patients with Raised Titres of Complement-fixing Antibodies to Cytomegalovirus (C.M.V.)

\begin{tabular}{|c|c|c|c|c|c|}
\hline M. & $<1$ & $\begin{array}{r}1 / 10-1 \\
5\end{array}$ & $\begin{array}{r}1 / 40-1 \\
20\end{array}$ & $\underset{8}{1 / 160-1 / 320}$ & $\begin{array}{r}1 / 640-1 / 1 \\
2\end{array}$ \\
\hline
\end{tabular}
.

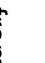


These patients were the only two to show any clinical signs in the eye or elsewhere of presumed infection with cytomegalovirus, but as can be seen from Table II 10 of the patients had high antibody titres and, more important, six showed a rising titre during the period of observation.

\section{GLAUCOMA}

Three patients had intraocular pressure above $20 \mathrm{~mm} \mathrm{Hg}$ when first seen. In one the intraocular pressures were found to be normal at subsequent examinations, as were the discs, corneoscleral angle, and visual fields. The second patient, a 21-year-old woman, was one of the patients with posterior subcapsular cataracts and had received $7 \cdot 7 \mathrm{~g}$ of prednisone in the first three months postoperatively and had intraocular pressures persistently around $25 \mathrm{~mm} \mathrm{Hg}$. Her discs were flat, the corneoscleral angles normal, and the visual fields full. It was not possible to reduce her steroids to see if this produced a fall in the intraocular pressures. The third patient, a 38-year-old man, was similarly one of those with posterior subcapsular cataracts, and had received 8.8 and $14.1 \mathrm{~g}$ of prednisone in the first 3 and 12 months postoperatively. When first seen his intraocular pressures were $38 \mathrm{~mm} \mathrm{Hg}$ on the right and $40 \mathrm{~mm} \mathrm{Hg}$ on the left, his corneoscleral angles were normal, but his right visual field showed an early upper arcuate scotoma. His steroid dosage was reduced and two weeks later his intraocular pressure had dropped to $26 \mathrm{~mm} \mathrm{Hg}$ right and $30 \mathrm{~mm} \mathrm{Hg}$ left.

Hemianopic Field Defect.-One patient had previously developed a right homonymous field defect together with a paraplegia due to a transverse myelitis. The field defect was hemianopic in the right eye and quadrantic in the left, and such an incongruous homonymous field defect was thought possibly to have arisen from a lesion in the optic tracts, probably not related to his renal condition.

\section{Discussion}

The early posterior subcapsular cataracts in these patients would undoubtedly appear to be steroid-induced. Their clinical appearance, close correlation to the highest steroid dosages, and absence in patients with similar renal conditions before transplantation confirm this. Other possible cataractogenic causes such as deep $x$-ray therapy and cytotoxic drugs were not present in all nine cases and had been used in other patients who had not developed cataracts. In fact statistical analysis showed that the only significant correlation $(P<0.05)$ was between these cataracts and the total steroid dosages. No similar correlations were found with the other therapeutic agents. One patient, although he fulfilled the above criterion, also had a bilateral intraocular infection and his cataracts could not therefore be definitely ascribed to the steroids. Cataracts induced by systemic steroid therapy are well documented (Black et al., 1960; Giles et al., 1962; Williamson et al., 1969), but most reports concern patients with chronic conditions who have been receiving moderate doses of steroids for many years. In these reports no cataracts appeared before two years, and the usual period was four years. Although it is not possible in this present series to state the time at which the cataracts first appeared, all but two of the patients had developed cataracts when seen for the first time within two years of operation.

Clearly the rate of development of these cataracts is accelerated with these massive steroid dosages. Steroid-induced glaucoma has been frequently reported when topical steroids are used (Miller 1956; Goldman, 1962; Burde and Becker, 1970), but it is of more rare occurrence when systemic steroids are used (Harris, 1960; Williamson et al., 1969). The 38-yearold man with severely increased intraocular pressures and early glaucomatous field defects who had received $14 \cdot 1 \mathrm{~g}$ of predni- sone in his first postoperative year appeared to be such a case. He had no other ocular abnormality to account for his raised intraocular pressure and, more important, the pressures fell with a reduction in his steroid dosage. He had no family history of glaucoma and it was not possible to examine his family.

The two cases of acute retinitis caused more concern in that the responsible agent produces extensive irreversible damage to the retina and hence the sight, and at the moment no effective treatment is available. This retinitis is probably due to cytomegalovirus for, although no histological evidence of typical inclusion bodies in the retinal cells was available in these cases, the diagnosis was suggested by the fourfold rise in the titre of complement-fixing antibodies to cytomegalovirus and the close clinical similarities between these two cases and a reported case (de Venecia et al., 1971) of acute retinitis in which confirmatory histological evidence was found at necropsy. Cytomegalovirus has been shown to be more widespread in the general population than at one time thought (Stern and Elek, 1965; Embil et al., 1969), and reports of cytomegalovirus infection in patients after renal transplantation are increasing (Hedley-White and Craighead, 1965; Kanich and Craighead, 1966; Craighead et al., 1967; Rifkind et al., 1967). Most of the patients are asymptomatic and the diagnosis is made by serological tests or by the identification of typical inclusion bodies in cells from the urine (Bossen et al., 1969) or peripheral blood (Armstrong et al., 1971). Several suggestions have been made about the source of infection in these patients. A reactivation of a latent infection has been suggested (Wong and Warner, 1962), and Rifkind (1966) pointed out that such a reactivation occurs with the varicella/zoster virus in the presence of similar immunosuppressive therapy.

Most workers, however, now seem to accept that the infection is of a primary nature either by direct spread from other patients (Kanich and Craighead, 1966) or by transfusion with donated blood containing cytomegalovirus. This theory is supported by the increasing evidence of the close association between the cytomegalovirus and the postransfusion syndrome (Kääriäinen et al., 1966; Lang et al., 1968; Lang and Hanshaw, 1969), the high titre of antibodies to cytomegalovirus in patients having undergone major surgery (Paloheimo et al., 1968; Stevens et al., 1970), and the more recent isolation of the virus from the leucocyte fraction of asymptomatic blood donors (Diosi et al., 1969). It seems however, from this report, that before an overt cytomegalovirus infection can develop a combination must exist of an asymptomatic viraemia, probably introduced via repeated blood transfusions, and a patient receiving excessive immunosuppressive therapy, particularly if this includes cyclophosphamide. Of the 10 patients with high and rising titres to cytomegalovirus only two were receiving excessive immunosuppressive therapy, and these two subsequently developed acute retinitis, together, in one patient, with an acute parotitis and pneumonitis.

Despite the widespread nature of this virus in renal transplant patients, this distressingly destructive retinitis is rare. Only four cases have been reported in adults (Smith, 1964; Wallow, 1969; de Venecia et al., 1971; Ashton and Cunha Vaz, 1966), but numbers will presumably grow with the increase in organ transplantation and the use of immunosuppressive and cytotoxic drugs. Clearly the patients at risk as regards ocular complications are those in whom a vigorous and prolonged rejection phenomenon has necessitated the persistent use of immunosuppressive drugs in high doses. It therefore seems reasonable to screen such patients from an ocular point of view with special reference to the retina, lens, and intraocular pressure, the last being of particular importance if a positive family history of glaucoma is present. Similarly a rising antibody titre to cytomegalovirus would alert one to the possibility of retinal damage.

Treatment of the cataracts at this stage is unnecessary, but presumably if the patients survive and continue with the high doses of steroids the cataracts will progress eventually to require surgical extraction. Treatment of the presumed cytomegalovirus retinitis is much less satisfactory and ideally would be avoided by 
removing in the first place the need for such extensive immunosuppressive therapy by attempting to achieve the best possible tissue match before operation.

We are grateful to Professor D. N. S. Kerr, Professor J. Swinney, and Mr. R. Taylor for permission to examine patients under their care.

\section{References}

Armstrong, D., Balakrishnan, S. L., Steger, L., Yu, B., and Stenzel, K. H. (1971). Arquives of Internal Medicine, 127, 111.

Ashton, N., and Cunha Vaz, J. G. (1966). Arquivos Portugueses de Oftalmologia, 18, Suppl., p. 39.

Black, R. L., Oglesby, $\dot{R}^{39}$, Von Sallman, L., and Bunim, J. (1960). fournal of the American Medical Association, 174, 166.

Bossen, E. H., Johnston, W.W., Amatulli, J., and Rowlands, D.T. (1969). American fournal of Clinical Pathology, 52, 340.

Burde, R. M., and Becker, B. (1970). Fournal of the American Medical Association, 213, 2075.

Craighead, J. E., Hanshaw, J. B., and Carpenter, C. B. (1967). Journal of the American Medical Association, 201, 725.

de Venecia, G., ZuRhein, M., Pratt, M. V., and Kisken, W. (1971). Archives of Ophthalmology, $86,44$.

Diosi, P., Moldovan, E., and Tomescu, N. (1969). British Medical fournal, 4, 660 .
Embil, J. A., Haldane, E. V., MacKenzie, R. A. E., and Van Rooyen, C. E. (1969). Canadian Medical Association fournal, 101, 730.

Giles, C. L., Mason, G. C., Duff, I. F., and MacLean, J. A. (1962). Fournal of the American Medical Association, 182, 719.

Goldman, H. (1962). Archives of Ophthalmology, 68, 621.

Harris, J. L. (1960). American fournal of Ophthalmology, 49, 351.

Hedley-White, E. T., and Craighead, J. E. (1965). New England fournal of Medicine, 272, 473

Kääriäinen, L., Klemola, E., and Paloheimo, J. (1966). British Medical fournal, 1, 1270.

Kanich, R. E., and Craighead, J. E. (1966). American fournal of Medicine, 40, 874.

Kern, R. Zaruba, K., and Scheitlin, W. (1970). Ophthalmic Research, 1, 21. Lang, D. J., and Hanshaw, J. B. (1969). New England fournal of Medicine, $280,1145$.

Lang, D. J., Scolnick, E. M., and Willerson, J. T. (1968). New England Fournal of Medicine, 278, 1147.

Miller, S. J. H. (1956). Transactions of the Ophthalmological Society of the United Kingdom, 85, 289.

Paloheimo, J. A., Van Essen, R., Klemola, E., Kääriäinen, L., and Siltanen, P. (1968). American fournal of Cardiology, 22, 624

Rifkind, D. (1966). Fournal of Laboratory and Clinical Medicine, 68, 463.

Rifkind, D., Goodman, N., and Hill, R. B. (1967). Annals of Internal Medicine, 66, 1116

Smith, M. E. (1964). Archives of Ophthalmology, 72, 44

Stern, H., and Elek, S. D. (1965). Fournal of Hygiene, 63, 79

Stevens, D. P., Barker, L. F. Ketchman, A. S., and Meyer, H. M. (1970) Fournal of the American Medical Association, 211, 1341 .

Wallow, I. (1969). Berichte der Deutschen Ophthalmologischen Gesellschaft $70,55$.

Williamson, J., et al. (1969). British fournal of Ophthalmology, 53, 361.

Wong, T. W., and Warner, N. E. (1962). Archives of Pathology, 74, 403.

\title{
Liquor Bilirubin Levels and False Prediction of Severity in Rhesus Haemolytic Disease
}

\author{
B. R. PRIDMORE, E. G. ROBERTSON, W. WALKER
}

British Medical fournal, 1972, 3, 136-139

\section{Summary}

Liquor bilirubin levels gave a false prediction of outcome for the fetus in 80 out of 716 rhesus-sensitized women referred for treatment during 1965-9. Trauma caused by amniocentesis seemed to be responsible for an increase in the severity of immunization in a significant proportion of cases. In addition, contamination of liquor samples by plasma, particularly fetal plasma, completely invalidated liquor bilirubin estimations. Errors in estimation of gestational length were also found to be associated with misleading results and a poor fetal prognosis.

\section{Introduction}

Variations in the level of bilirubin in liquor amnii are closely related to the severity of rhesus haemolytic disease in the fetus and are used to identify those patients in whom special treatment is needed to prevent intrauterine death. Liquor is obtained by amniocentesis, but as this is potentially dangerous we prefer initially to select patients for this investigation on the basis of the previous obstetric history (Walker, 1968).

First Affected Pregnancy.-Initial amniocentesis is performed at 31 weeks, but only if the maternal antibody titre by the indirect Coombs technique against Group $\mathrm{OR}_{1} \mathrm{R}_{2}$ cells is $1: 16$ or greater.

Department of Obstetrics and Gynaecology, University of Newcastle upon Tyne

B. R. PRIDMORE, M.B., M.R.C.o.G., Registrar

E. G. ROBERTSON, M.D., M.R.c.o.G., Senior Lecturer

Department of Child Health, University of Newcastle upon Tyne W. WALKER, M.D., Reader
Previous Liveborn Affected Infant.-Initial amniocentesis is performed at 31 weeks. No account is taken of the maternal antibody titre.

Previous Stillbirth due to Rhesus Disease (Including Liveborn Hydrops Fetalis).-Amniocentesis is first performed at between 20 and 24 weeks of pregnancy. No account is taken of maternal antibody titre.

Incorrect predictions occur; high levels of bilirubin are sometimes found in liquor when the infant is not severely affected, and, conversely, low levels can be associated with severe rhesus haemolytic disease or even stillbirth. "Over" prediction can lead to unnecessary intrauterine transfusion or premature induction, both of which are dangerous, while "under" prediction means that a fetus may die unnecessarily.

In the present study we examined cases in which an incorrect forecast of severity was made in order to determine whether a satisfactory explanation of failure is possible.

\section{Subjects and Method}

During 1965-9 810 rhesus-negative women with antibodies were booked for delivery in the Princess Mary Maternity Hospital and 716 of them had one or more specimens of liquor examined. For this investigation the patients were admitted to hospital overnight and amniocentesis was performed under strict aseptic precautions. The liquor, once obtained, was placed in a brown bottle to exclude light and the bilirubin level estimated within a few hours by the method described by Knox et al. (1965).

With a $0.5-\mathrm{cm}$ light path the spectrum is constructed through the visible range $360-630 \mathrm{~nm}$. The optical density difference between 520 and $490 \mathrm{~nm}$ wavelengths is measured and as this is a logarithmic function it may also be expressed as a transmittance ratio:

$\%$ transmission at $520 \mathrm{~nm}$ 